Article

\title{
Assessment of Heat-Affected Zone Softening of Hot-Press-Formed Steel over 2.0 GPa Tensile Strength with Bead-On-Plate Laser Welding
}

\author{
Kwangsoo Kim ${ }^{1,2}$, Namhyun Kang ${ }^{1, *}$ (D), Minjung Kang ${ }^{3, *}$ and Cheolhee Kim ${ }^{3,4}$ (D) \\ 1 Department of Materials Engineering, Pusan National University, Changjeon-Dong, Pusan 46241, Korea; \\ kwangsoo999@naver.com \\ 2 Production Support Team, DNV Korea, U-dong, Pusan 48120, Korea \\ 3 Welding and Joining Research Group, Korea Institute of Industrial Technology, \\ Songdodong Incheon 21999, Korea; chkim@kitech.re.kr \\ 4 Department of Mechanical and Materials Engineering, Portland State University, Portland, OR 97201, USA \\ * Correspondence: nhkang@pusan.ac.kr (N.K.); kmj1415@kitech.re.kr (M.K.)
}

check for updates

Citation: Kim, K.; Kang, N.; Kang, M.; Kim, C. Assessment of Heat-Affected Zone Softening of Hot-Press-Formed Steel over 2.0 GPa Tensile Strength with Bead-On-Plate Laser Welding. Appl. Sci. 2021, 11, 5774. https://doi.org/10.3390/ app11135774

Academic Editor:

Francesco Colangelo

Received: 1 June 2021

Accepted: 15 June 2021

Published: 22 June 2021

Publisher's Note: MDPI stays neutral with regard to jurisdictional claims in published maps and institutional affiliations.

Copyright: (c) 2021 by the authors. Licensee MDPI, Basel, Switzerland. This article is an open access article distributed under the terms and conditions of the Creative Commons Attribution (CC BY) license (https:/ / creativecommons.org/licenses/by/ $4.0 /)$.

\begin{abstract}
High-strength hot-press-formed (HPF) steels with a fully martensitic microstructure are being widely used in the fabrication of automotive body structure, and 2.0 GPa-strength HPF steel has recently been commercially launched. However, heat-affected zone (HAZ) softening is unavoidable in welding martensitic steel. In this study, the HAZ softening characteristic of 2.0 GPa HPF steel was investigated by applying a high-brightness laser welding process, wherein the heat input was controlled by varying the welding speed. Microstructural evaluation and hardness test results showed that the base metal with a fully martensitic microstructure was changed to the same type of fully martensitic microstructure in the weld metal, while relatively soft microstructures of tempered martensite and ferrite phase were partially formed in the intercritical HAZ (ICHAZ) and subcritical HAZ (SCHAZ) areas. In the tensile test, the joint strength was 10-20\% lower than that of the base metal, and the fracture initiation was estimated at the ICHAZ/SCHAZ boundary, where the lowest hardness was confirmed by the nanoindentation technique.
\end{abstract}

Keywords: hot-press-formed steel; high-strength steel; 2 GPa strength; laser welding; heat-affected zone; softening; tempered martensite; ferrite

\section{Introduction}

The strength of steel utilized in the automobile body structures has been increasing rapidly, and the proportion of martensite-based ultra-high-strength steel (UHSS) has been expanding drastically in the last two decades [1-4]. Among modern martensite-based UHSS, fully martensitic steel and hot-press-formed (HPF) steel have higher strength owing to the higher martensitic phase fraction than that in martensite-ferrite dual-phase (DP) steel and transformation-induced plasticity steel, which have a partial martensite fraction [4-6].

HPF steel, a boron-alloy steel, has a ferritic-pearlitic microstructure with a tensile strength of approximately $600 \mathrm{MPa}$ before the HPF process. During the HPF process, an HPF-steel sheet is heated for complete austenization and then quenched in a water-cooled die; this process enables the achievement of high dimensional accuracy owing to the high temperature forming process and a fully martensitic microstructure formation owing to the rapid cooling. Based on the process characteristics, HPF is also termed press hardening, hot forming, or die quenching. Since 2010, HPF steel has been widely commercialized in the automotive industry, and 22MnB5 steel with a tensile strength of $1.5 \mathrm{GPa}$ has been most commonly applied [7]. Many automotive companies have successfully applied HPF steel to passenger-safety-related components, such as the bumper beams and center pillars, and automobile manufacturers are focused on expanding their applications to higher-grade HPF steel with higher carbon content [8]. 
Because HPF steel has a fully martensitic microstructure, relatively soft tempered martensite is formed at the heat-affected zone (HAZ) while welding: this is termed as the HAZ softening effect. The HAZ softening effect is unavoidable in welding the martensitebased UHSS; therefore, laser welding with a relatively low heat input is preferred to minimize the size and magnitude of HAZ softening. Most previous studies have investigated the laser weldability of $1.5 \mathrm{GPa}$ grade HPF steel using a $\mathrm{CO}_{2}$ laser [9] and high brightness lasers [10] and found substantial hardness degradation of the HAZ when the peak temperature was near the austenization $\left(A_{1}\right)$ temperature. Steel manufacturers such as SSAB AB and ThyssenKrupp Steel released higher grades of HPF steel. Furthermore, the laser overlap weldability has been evaluated on 1.8 GPa grade and 1.9 GPa grade HPF steel [11]. The detrimental influence of surface layers such as the AISi coating layer and the surface oxide layer on the laser-weld strength was investigated on 1.5 GPa HPF steel [12] and 1.8 GPa HPF steel [13]. The commercial 2.0 GPa HPF steel has been launched, but studies on the welding of 2.0 GPa grade HPF steel have not been reported yet.

In this study, the mechanical and metallurgical behavior of laser welds was investigated on 2.0 GPa HPF steel. A high brightness laser was chosen as the power source to minimize the thermal effect on the welds, and the microstructural transformation at different locations was observed by microscopy. The cause of HAZ softening and its effect on the tensile strength of the welds were studied through microstructural analysis.

\section{Experimental Procedure}

Boron-alloyed steel, Docol ${ }^{\circledR}$ PHS CR 2000, with a thickness of $1.2 \mathrm{~mm}$ was used as the base metal (BM). The specimens were machined to a dimension of $150 \times 120 \mathrm{~mm}$ (Figure 1), and the oxide scales on the specimen surface were removed using fine sandpaper to prevent dilution of the oxide layer into the weld metal (WM) [13]. The chemical composition of the $\mathrm{BM}$ was analyzed using an optical emission spectrometer (Table 1), and it was matched with the range in the technical specifications provided by the steelmaker SSAB AB [14]. Then, the specimens were heat-treated according to the manufacturer's guidelines. The specimens were heated for $5 \mathrm{~min}$ in a furnace at a temperature of $950{ }^{\circ} \mathrm{C}$ to complete the austenitic phase transformation and then quenched in a water-cooled die where the temperature was maintained constantly at $25^{\circ} \mathrm{C}$. The cooling rate in the cooling die was estimated to be $100 \mathrm{~K} / \mathrm{s}$.

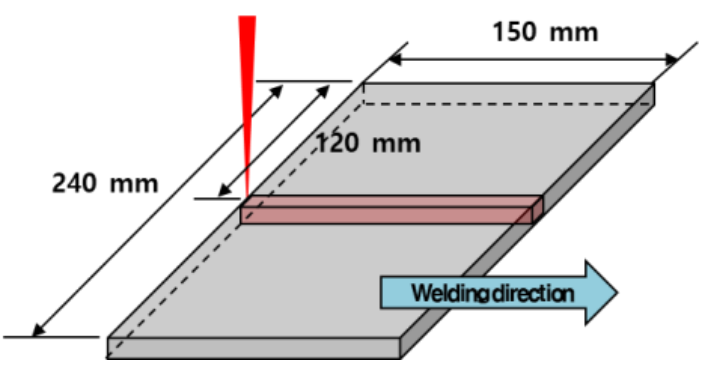

Figure 1. Welding joint preparation.

Table 1. Chemical composition of the base metal (wt \%).

\begin{tabular}{ccccccccc}
\hline $\mathbf{C}$ & $\mathbf{S i}$ & $\mathbf{M n}$ & $\mathbf{P}$ & $\mathbf{S}$ & $\mathbf{C r}$ & $\mathbf{B}$ & $\mathbf{N b}$ & $\mathbf{T i}$ \\
\hline 0.346 & 0.25 & 1.20 & 0.011 & 0.001 & 0.14 & 0.0015 & 0.044 & 0.01 \\
\hline
\end{tabular}

A fiber laser system (IPG photonics, Oxford, MA, USA) with a wavelength of $1070 \mathrm{~nm}$ with the laser output power set at $2 \mathrm{~kW}$ was used. The laser beam was delivered to a laser optics (IPG photonics, Oxford, MA, USA) device with a focal distance of $200 \mathrm{~mm}$ through an optical fiber with a diameter of $200 \mu \mathrm{m}$. The laser beam was irradiated perpendicularly onto the specimen placed at the focal position. At the focal point the laser beam had a 
beam diameter of $0.27 \mathrm{~mm}$ (Figure 2). The welding speed was varied from 6 to $8 \mathrm{~m} / \mathrm{min}$ : shielding gas was not supplied in this study.

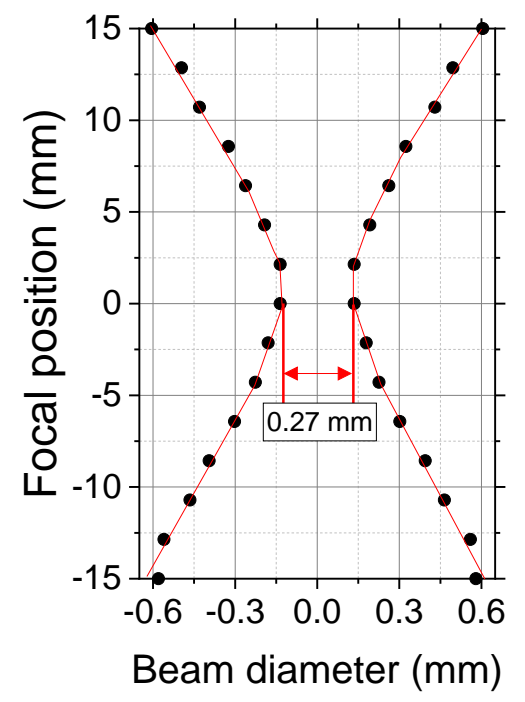

Figure 2. Measured laser beam profile.

Mechanical and metallurgical tests were performed on the welded specimens. After laser welding, three tensile-test specimens were machined based on the ISO 4136 standard for each condition (Figure 3 ) and the static tensile tests were carried out at a head speed of $1 \mathrm{~mm} / \mathrm{min}$ (Shimadzu, Kyoto, Japan). The welded specimen was polished and etched with $3 \%$ nital solution ( $3 \mathrm{~mL} \mathrm{HNO}_{3}$ and $100 \mathrm{~mL}$ ethanol) and the microstructure was observed by optical microscopy (OM, Olympus, Kyoto, Japan) and field-emission scanning electron microscopy (FE-SEM, Thermo Fisher Scientific, Waltham, MA, USA). The micro-Vickers hardness (Matsuzawa, Akita, Japan) was measured on the cross-section with an indent spacing of $0.1 \mathrm{~mm}$ along the specimen centerline, according to the ASTM E384-99 standard; the applied load and holding time for hardness measurement were $1.96 \mathrm{~N}$ and $10 \mathrm{~s}$, respectively. In addition, nanoindentation hardness tests were carried out in the lower-hardness region between the intercritical HAZ (ICHAZ) and the subcritical HAZ (SCHAZ) with a load of $0.2 \mathrm{~N}$ and a holding time of $20 \mathrm{~s}$, according to the ISO 14577-1:2015 standard.

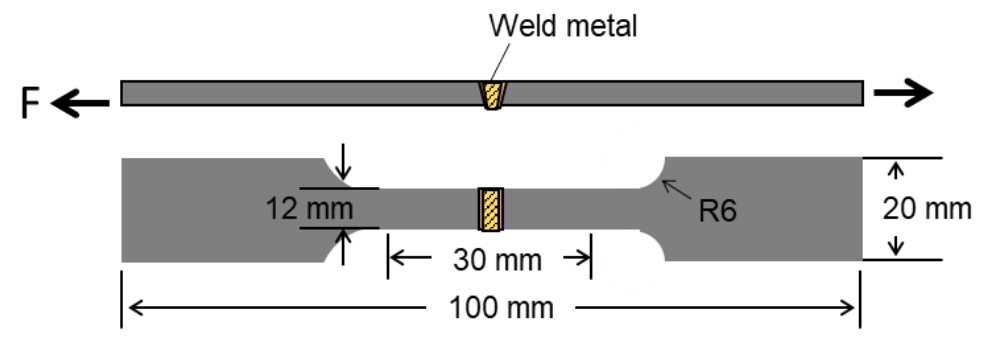

Figure 3. Configuration of tensile test specimen.

\section{Results and Discussion}

\subsection{Microstructure and Mechanical Properties of Base Metal}

Figure 4a shows the BM microstructure. Martensite blocks consisting of parallel laths were observed with no indication of carbides precipitation and retained austenite. The BM had a fully martensitic microstructure with an average hardness of $609 \mathrm{HV}$. Figure $4 \mathrm{~b}$ shows the stress-strain curves of the BM after the HPF process: the average values of tensile strength and elongation were $2.08 \mathrm{GPa}$ and $3.36 \%$, respectively. 


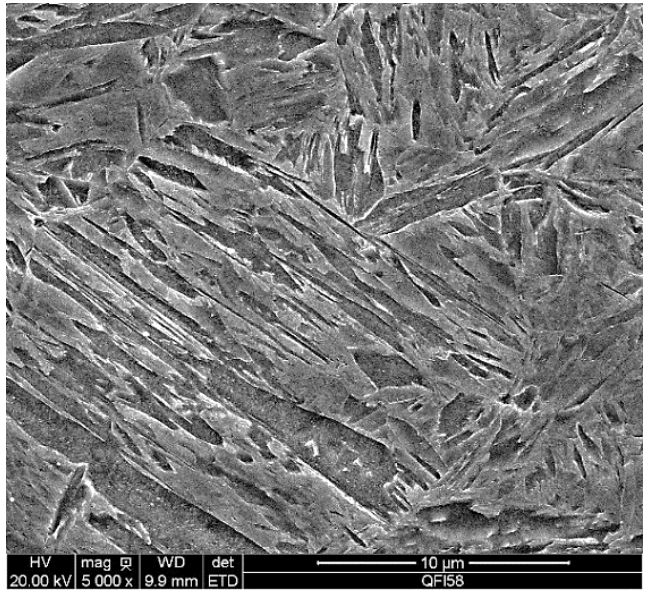

(a)

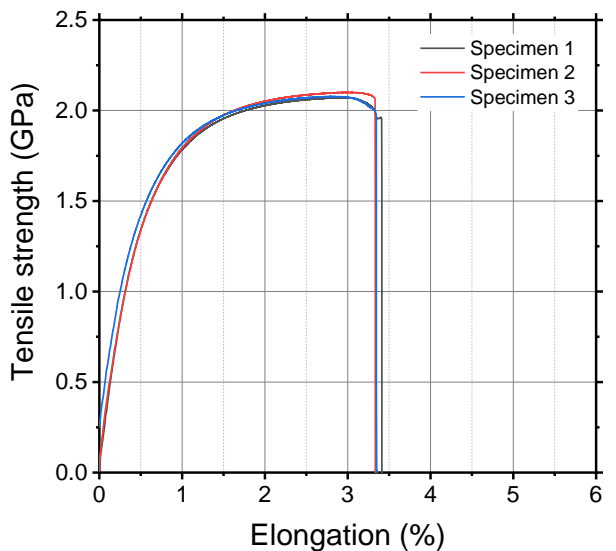

(b)

Figure 4. Characteristics of base material: (a) SEM image of the base metal (5000 $\times$ magnification) and (b) tensile test result.

\subsection{Welding Test Result}

Full penetration was achieved under bead-on-plate welding conditions, and the higher the welding speed, the narrower the bead width. Sound weld beads were formed except for a slight underfill (Figure 5). In the cross-sectional images, white bands were observed in the HAZ between the WM and BM. According to a previous study [12], that white band region indicated the ICHAZ, which had a peak temperature between the austenite transformation temperatures of $A_{C 1}$ and $A_{C 3}$. The ICHAZ of laser-welded HPF steel contains relatively soft ferrite owing to partial austenization, while other regions comprise martensite and tempered martensite.

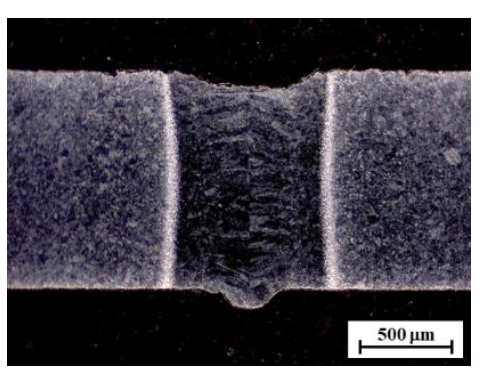

(a)

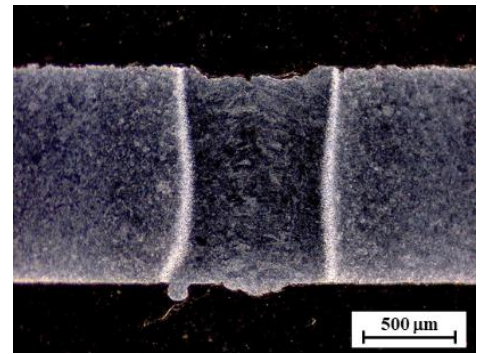

(b)

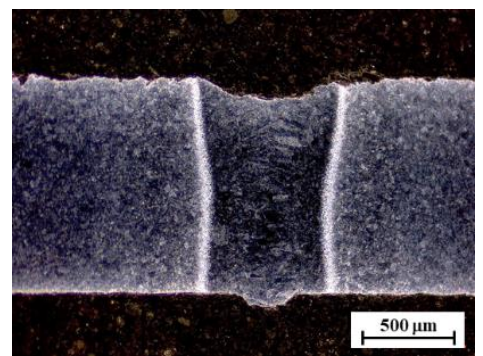

(c)

Figure 5. Bead-on-plate weld cross-sections according to welding speed (45× magnification): (a) $6 \mathrm{~m} / \mathrm{min}$; (b) $7 \mathrm{~m} / \mathrm{min}$; (c) $8 \mathrm{~m} / \mathrm{min}$.

The microstructure of the weld specimen with a welding speed of $7 \mathrm{~m} / \mathrm{min}$ was analyzed using OM and SEM. The WM has a microstructure of lath martensite owing to the high cooling rate of laser welding (Figure 6a), which is similar to that of the BM (Figure 4a). A previous study on laser welding on 1.5 GPa HFP steel reported that the WM of 1.5 GPa HFP steel has a finer martensitic microstructure with a smaller packet size than the BM [15]. Although the cooling rate during laser welding is much faster than that during the HPF process $[16,17]$, the BM of 2.0 GPa HPF was almost fully hardened through the HPF process owing to the high carbon content, which resulted in a similar microstructure in both the BM and WM. The upper critical HAZ (UCHAZ), where the peak temperature is between the $A_{C 3}$ and the melting temperatures, is composed of coarse grain HAZ (CGHAZ) adjacent to the WM and fine grain HAZ (FGHAZ) adjacent to the ICHAZ. Both CGHAZ and FGHAZ showed a martensitic structure owing to the high cooling rate. The martensite packet in the FGHAZ is slightly finer than that in the CGHAZ, but the microstructural difference is not significant (Figure $6 b, c)$ : the microstructure of the 
ICHAZ differs from that of other regions. In the ICHAZ, martensite was formed in the prior-austenite grain boundary, and ferrite (or ferrite/carbide) was formed in the rest of the areas (Figure 6d). Ferrite has different polishing and etching characteristics from those of martensite and tempered martensite, which resulted in white bands on the cross-sections in Figure 5. In the SCHAZ, the austenite phase transformation did not occur because the peak temperature was below the $\mathrm{A}_{\mathrm{C} 1}$ temperature, and tempered martensite with carbide precipitates was observed (Figure 6e).
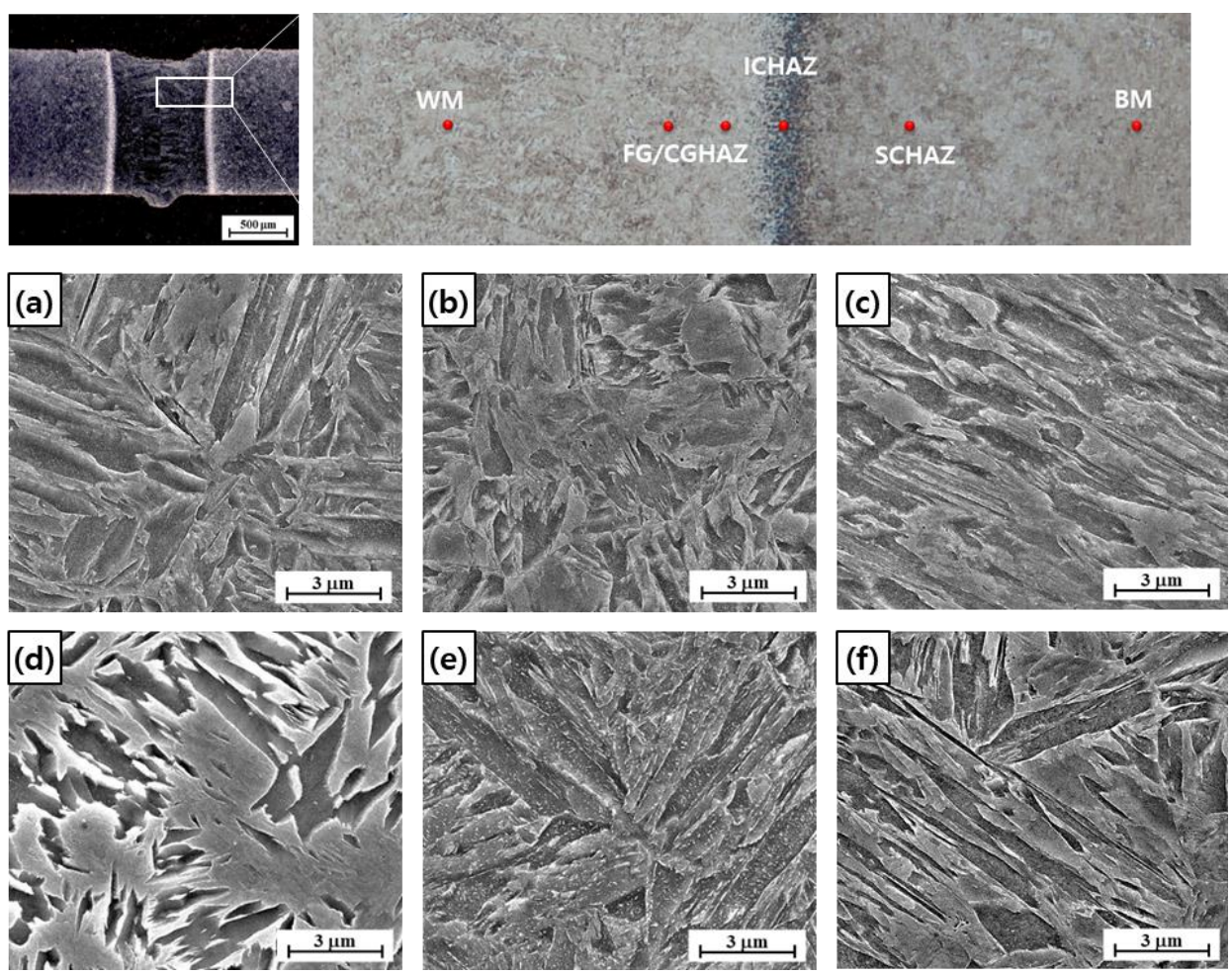

Figure 6. SEM images of bead-on-plate welds (welding speed: $7 \mathrm{~m} / \mathrm{min}$ ): (a) weld metal; (b) coarse grain heat-affected zone; (c) fine grain heat-affected zone; (d) intercritical heat-affected zone; (e) subcritical heat-affected zone; (f) base metal.

Compared to the BM, the WM and UCHAZ had similar or higher hardness, while lower hardness was measured in the ICHAZ and SCHAZ (Figure 7). As the welding speed increased from 6 to $8 \mathrm{~m} / \mathrm{min}$, the width of the high-hardness zone of the WM and UCHAZ decreased. The softening of the ICHAZ and SCHAZ was caused by the formation of a relatively soft microstructure of ferrite and tempered martensite, as shown in Figure 6.

Nanoindentation hardness testing was carried out in the lower-hardness area of the ICHAZ and SCHAZ on the specimen with a welding speed of $7 \mathrm{~m} / \mathrm{min}$. Hardness was measured at 13 locations along a line oblique to the HAZ boundaries (Figure 8a). The lowest hardness value of $323.7 \mathrm{HV}$ was observed at location 7 (Figure 8b), which was placed on the exact boundary between the ICHAZ and SCHAZ as shown in the SEM image (Figure 8a). Ferrite and tempered martensite were simultaneously observed in the microstructure of the lowest-hardness zone (Figure 9). It was confirmed that the most softened location was the ICHAZ/SCHAZ boundary where the peak temperature was equal to the $\mathrm{A}_{\mathrm{C} 1}$ temperature. 


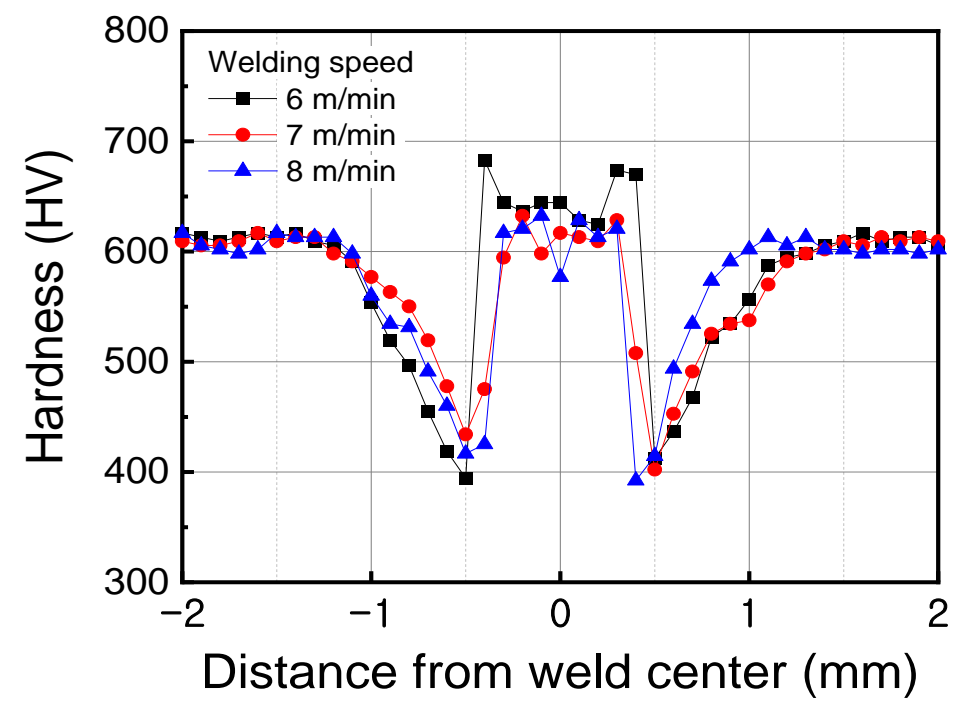

Figure 7. Vickers hardness profiles of bead-on-plate welds corresponding to welding speed.

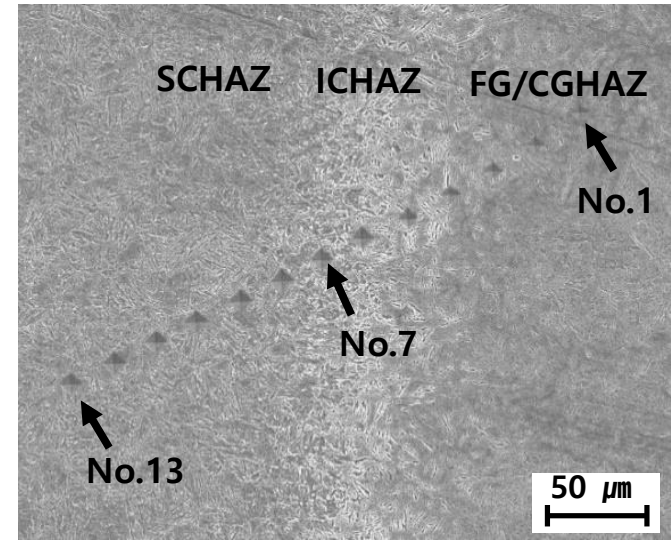

(a)

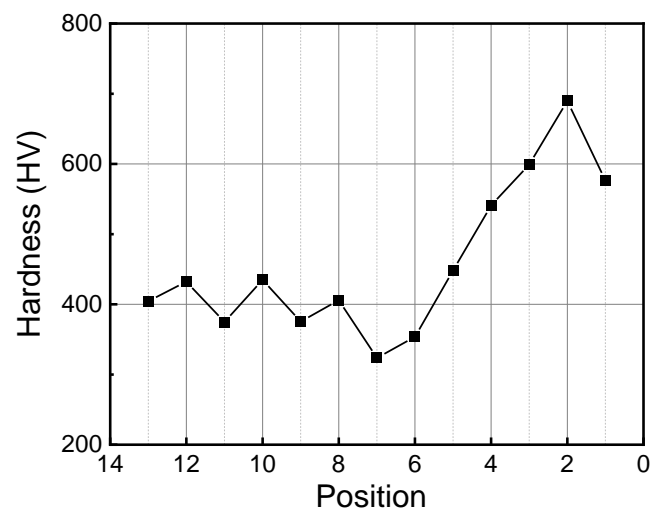

(b)

Figure 8. Nanoindentation hardness test result in ICHAZ and SCHAZ. (a) Indentation location and (b) measured hardness (welding speed: $7 \mathrm{~m} / \mathrm{min}$ ).

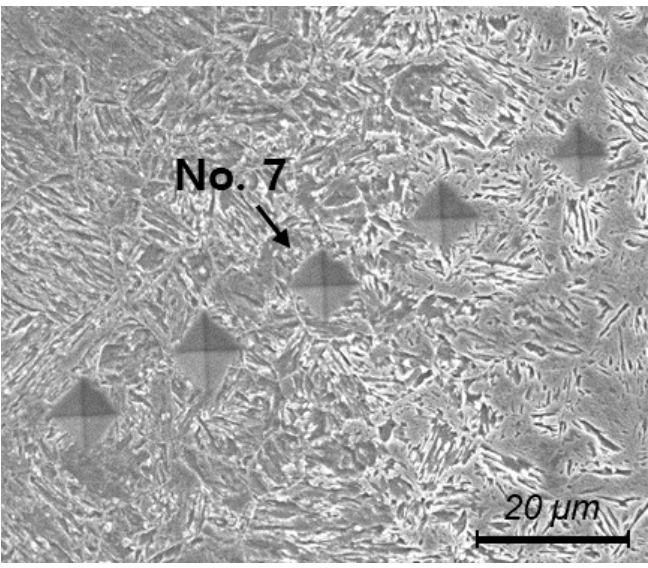

(a)

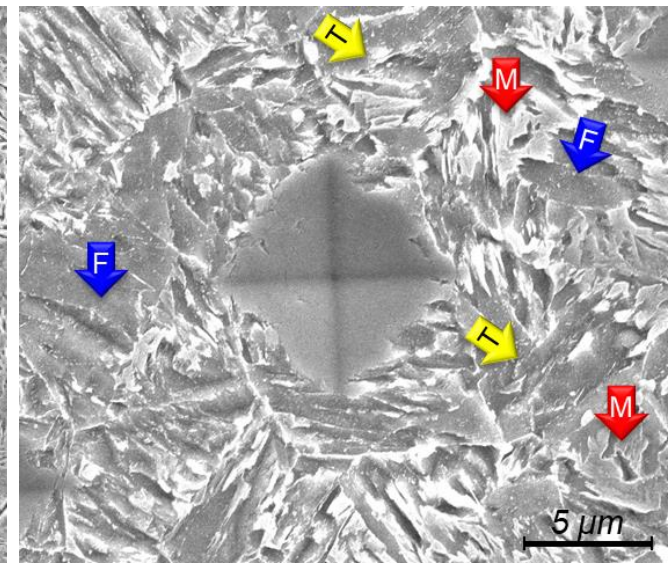

(b)

Figure 9. Microstructure around the indentation location no. 7: (a) 1500× magnification and (b) $5000 \times$ magnification (M: Martensite, F: Ferrite, T: Tempered Martensite). 
In the range of welding speeds of $6-8 \mathrm{~m} / \mathrm{min}$, there was no significant variation in the hardness of the WM and the tensile strength of the welds, except for a slightly lower tensile strength at the lowest welding speed (Figure 10). The crack initiation location in the tensile tests is indicated by the red arrows in Figure 11. The fractures were estimated to be initiated at the boundary of the ICHAZ and SCHAZ, which is consistent with the location of the lowest hardness in Figures 7 and 8. An examination of the fracture surfaces revealed that the fracture mode was ductile (Figure 12). The fracture surfaces contain dimple features that indicate a ductile fracture, and there are finer dimples at the fracture surface of the top and bottom parts than those of the middle part. Moreover, a surface similar to the cleavage facet, indicated by red arrows in Figure 12, was observed in the middle part of the fractured surface.

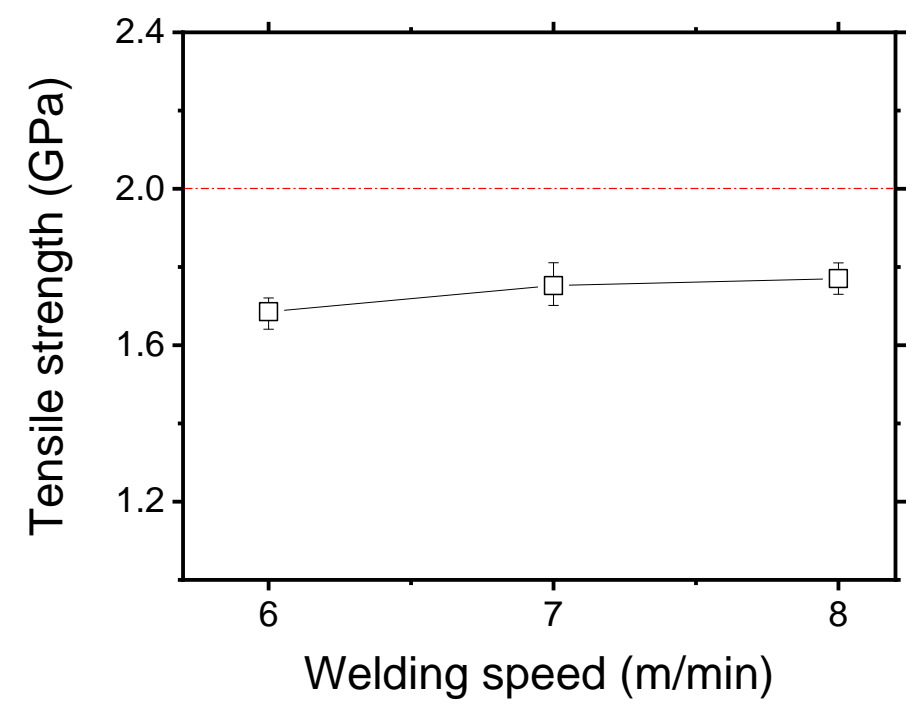

Figure 10. Tensile strength of bead-on-plate welds.
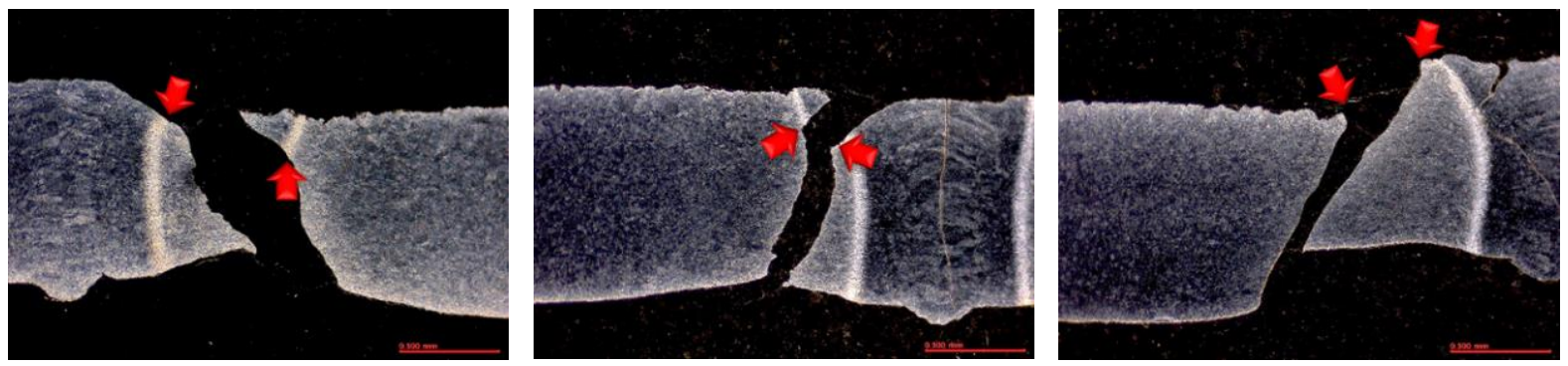

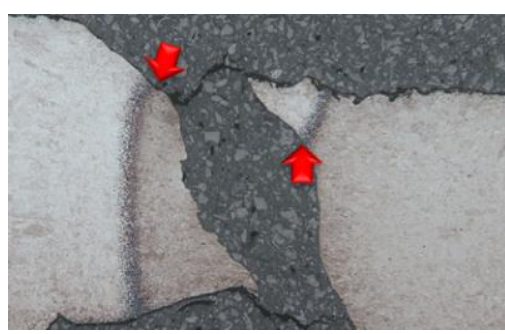

Welding speed $6 \mathrm{~m} / \mathrm{min}$

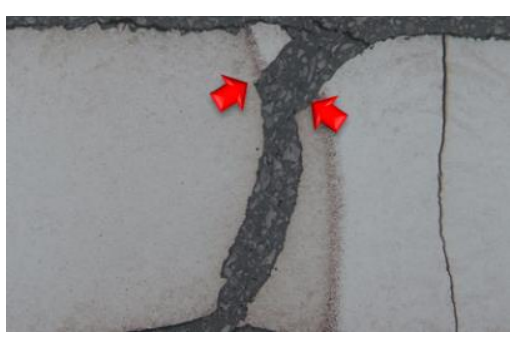

Welding speed $7 \mathrm{~m} / \mathrm{min}$

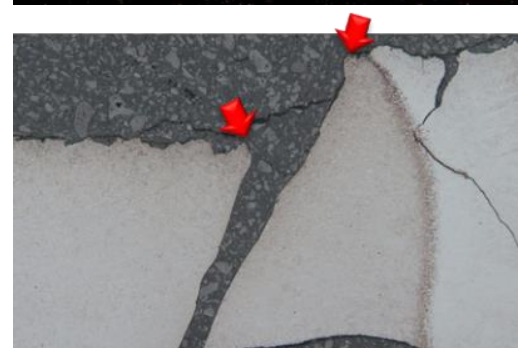

Welding speed $8 \mathrm{~m} / \mathrm{min}$

Figure 11. Fractured specimens after tensile test. 


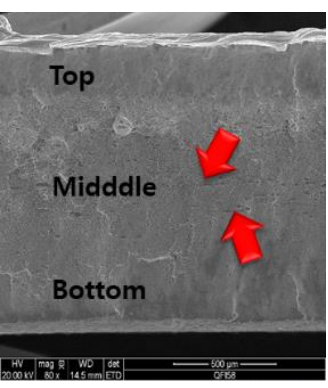

$1 \mathrm{k} \times$

$5 k \times$
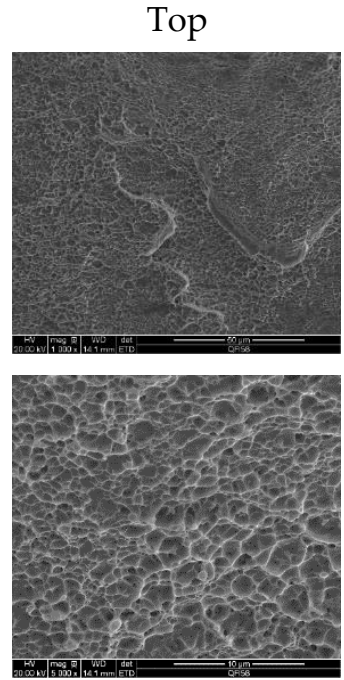

Middle
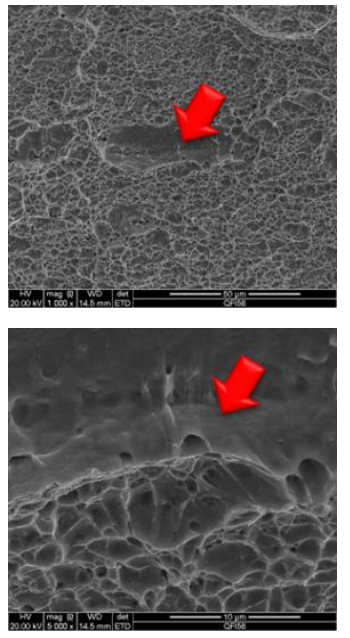

Bottom
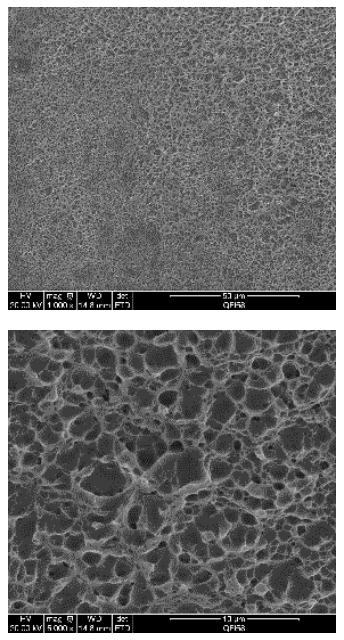

Figure 12. Scanning electron microscopy (SEM) images of fractured specimen (welding speed: $7 \mathrm{~m} / \mathrm{min}$ ).

\section{Conclusions}

In this study, laser welding was applied to HPF steel with 2.08 GPa strength, and the following results were obtained:

(1) The tensile strength of the laser BOP joint was degraded over a range between 1.6 GPa and 1.8 GPa. A slightly lower strength was obtained at the lowest welding speed.

(2) The hardness of the WM and the UCHAZ is similar or higher than that of the BM, while relatively lower hardness was measured in the ICHAZ and the SCHAZ, which is estimated as a fracture initiation location in the tensile test.

(3) The lowest hardness area in the HAZ coincided exactly with the boundary of the ICHAZ and the SCHAZ, composed of the soft microstructures of ferrite and tempered martensite, developed at the peak $\mathrm{A}_{\mathrm{C} 1}$ temperature.

(4) When designing the parts using HPF steel, it is necessary to understand the thermal softening and microstructural non-uniformity of the welded joint.

Author Contributions: Investigation, K.K. and C.K.; Methodology, K.K. and N.K.; Supervision, N.K. and M.K.; Writing-original draft, K.K., M.K. and C.K.; Writing-review and editing, M.K. All authors have read and agreed to the published version of the manuscript.

Funding: This research was supported by the Future Material Discovery Project of the National Research Foundation of Korea (NRF) funded by the Ministry of Science, ICT and Future Planning (MSIP) of Korea (2016M3D1A1023534). We also acknowledge the financial support provided through the MOTIE (Ministry of Trade, Industry, and Energy) in Korea, under the Industrial Strategic Technology Development Program (20002809).

Institutional Review Board Statement: Not applicable.

Informed Consent Statement: Not applicable.

Data Availability Statement: Not applicable.

Conflicts of Interest: The authors declare no conflict of interest.

\section{References}

1. Senuma, T. Physical metallurgy of modern high strength steel sheets. ISIJ Int. 2001, 41, 520-532. [CrossRef]

2. Taub, A.; De Moor, E.; Luo, A.; Matlock, D.K.; Speer, J.G.; Vaidya, U. Materials for automotive lightweighting. Annu. Rev. Mater. Res. 2019, 49, 327-359. [CrossRef]

3. Skszek, T.W.; Zaluzec, M.; Conklin, J.; Wagner, D. MMLV: Project Overview. SAE Tech. Paper 2015-01-0407 2015, 1, 1-8.

4. Mallick, P.K. Materials, Design and Manufacturing for Lightweight Vehicles; Woodhead Publishing: Cambridge, UK, $2020 ;$ pp. 45-88. 
5. Maggi, S.; Murgia, M. Introduction to the metallurgic characteristics of advanced high-strength steels for automobile applications. Weld. Int. 2008, 22, 610-618. [CrossRef]

6. Ahn, Y.N.; Kang, M.J.; Kim, C.H. Analysis of laser weldments for dual-phase and martensitic steel sheets for automotive applications. Defect Diffus. Forum 2014, 353, 8-12. [CrossRef]

7. Karbasian, H.; Tekkaya, A.E. A review on hot stamping. J. Mater. Process. Technol. 2010, 210, 2103-2118. [CrossRef]

8. Taylor, T.; Fourlaris, G.; Evans, P.; Bright, G. New generation ultrahigh strength boron steel for automotive hot stamping technologies. Mater. Sci. Technol. 2014, 30, 818-826. [CrossRef]

9. Kim, C.-H.; Choi, J.-K.; Kang, M.-J.; Park, Y.-D. A study on the $\mathrm{CO}_{2}$ laser welding characteristics of high strength steel up to 1500 MPa for automotive application. J. Achiev. Mater. Manuf. Eng. 2010, 39, 79-86.

10. Kang, M.; Kim, C.; Lee, J. Weld strength of laser-welded hot-press-forming steel. J. Laser Appl. 2012, 24, 022004. [CrossRef]

11. Fahlström, K.; Persson, K.-A.; Larsson, J.K.; Ferrer, E.V. Evaluation of laser weldability of 1800 and 1900 MPa boron steels. J. Laser Appl. 2016, 28, 022426. [CrossRef]

12. Kim, C.; Kang, M.; Park, Y. Laser welding of Al-Si coated hot stamping steel. Procedia Eng. 2011, 10, 2226-2231. [CrossRef]

13. Kang, M.; Kim, C. Influence of surface oxide on mechanical properties of laser-welded hot-press-forming steel with strength of 1.8 GPa. J. Laser Appl. 2018, 30, 032415. [CrossRef]

14. DOCOL PRESS HARDENING STEEL Technical Brochure. Available online: https://www.ssab.com/products/brands/docol/ products / docol-phs-2000 (accessed on 25 March 2021).

15. Kang, M.J.; Kim, C.H. Analysis of laser and resistance spot weldments on press-hardened steel. Mater. Sci. Forum 2011, 695, 202-205. [CrossRef]

16. Ono, M.; Yoshitake, A.; Omura, M. Laser weldability of high-strength steel sheets in fabrication of tailor welded blanks. Weld. Int 2004, 18, 777-784. [CrossRef]

17. Han, T.-K.; Park, B.-G.; Kang, C.-Y. Hardening characteristics of $\mathrm{CO}_{2}$ laser welds in advanced high strength steel. Met. Mater. Int. 2012, 18, 473-479. [CrossRef] 